\title{
EFFECT OF ENVIRONMENTAL TEMPERATURE ON EXPERIMENTAL TRAUMATIC SHOCK IN DOGS ${ }^{1}$
}

\author{
By RENATO A. RICCA, K. FINK, LEONARD I. KATZIN, AND \\ STAFFORD L. WARREN \\ (From the Department of Radiology of the University of Rochester School of Medicine and Dentistry, \\ Rochester, N. Y.)
}

(Received for publication June 5, 1944)

\section{INTRODUCTION}

A survey of the recent reviews (1 to 3 ), and the many recent articles on experimentally produced shock, indicate that a variety of standardized procedures are used to study a fairly reproducible syndrome. It seems obvious, however, from the literature and our own experience, that even in the hands of experienced investigators, there is enough lack of reproducibility in these so-called standardized experiments to introduce a large element of confusion and controversy. Our experiments lead us to suggest that the influence of seasonal variations of laboratory temperatures can influence, if not actually control, the outcome of the shock experiments produced by muscle crushing by means of the modified Blalock press (4). It is apparent, therefore, that control of the environmental or room temperature is essential in the conduct of a standard shock experiment. The therapeutic applications of this possibility are obvious, and are verified by the experiments reported below. With room temperatures of $28^{\circ} \mathrm{C}$., the outcome of the 5-hour press experiment is fatal in 90 per cent of the cases, while with room temperatures of $16^{\circ} \mathrm{C}$., it is fatal in only a small percentage of the cases, all other conditions remaining the same.

Recently, others have indicated the therapeutic importance of the proper environmental temperature. Some investigators (5) have reported an optimal environmental temperature of $75^{\circ} \mathrm{F}$. for burn shock in rats. Others (6)

1 The work described in this paper was done under a contract, recommended by the Committee on Medical Research, between the Office of Scientific Research and Development and the University of Rochester School of Medicine and Dentistry. Part of the work was also assisted by grants in aid from the Rockefeller Foundation and the Fluid Research Fund of the University of Rochester. also report that environmental temperatures "in the neighborhood of mammalian body temperature" prolong the survival time in shock induced by intestinal trauma. Significant elevations in body temperature have been found to decrease the chance of survival, and shorten the survival period of the dog in shock as a result of muscle trauma (7).

The environmental temperature apparently controls the animal's body temperature elevation during the period of injury and the critical period immediately following it. Apparently, the chain of events which is necessary to produce the fatal outcome is activated and produced in an overwhelming degree only when the body temperature is in the febrile level. In order to prevent the development of fatal shock, therefore, therapeutic efforts should be directed toward maintaining nearly normal or even slightly subnormal temperatures.

\section{METHODS}

The experimental animals used in the Blalock type of press (4) experiment were dogs, generally ranging in weight from 15 to $27 \mathrm{kgm}$. Veterinary Nembutal anesthesia was administered intraperitoneally in all experiments. The initial dosage was $60 \mathrm{mgm}$., plus $30 \mathrm{mgm}$. per $\mathrm{kgm}$. body weight. Additional anesthetic was given as required, and in almost no case was anesthetic administered during the last hour before the press was removed and subsequent to the removal of the press.

Tissue injury and peripheral circulatory collapse were induced by confinement of one thigh of the dog in a press for a period of 5 hours. Usually within 1 hour after removal of the press, the dog showed evidence of shock. Blood samples for analyses were taken from the external jugular vein as follows: (a) $15 \mathrm{ml}$. just before anesthesia, (b) $40 \mathrm{ml}$. at 10 minutes following complete anesthesia, or immediately before the press was applied, (c) $15 \mathrm{ml}$. one-half hour before removal of the press, (d) $40 \mathrm{ml} .3$ hours after removal of the press, and (e) $40 \mathrm{ml}$. at exitus, or at 24 hours after removal of the press if the animal survived. Coagulation of blood was avoided by use of $2 \mathrm{mgm}$. of potassium oxalate per $\mathrm{ml}$. of whole blood. The 
following determinations were made on samples of the dog's blood. Plasma or serum protein concentration was done by the micro-Kjeldahl method. In fibrinogen determinations, the clot was formed by the method of Cullen and Van Slyke (8), and the nitrogen in the clot determined by the micro-Kjeldahl method. Whole blood non-protein nitrogen was determined by the method of Koch and McMeekin (9), urea by the method of Karr (10), creatine and creatinine by the method of Folin and Wu (11). Hematocrits, red cell osmotic fragility, and plasma or serum specific gravity were also done routinely on the blood samples. The specific gravities were done by the pycnometer method (12).

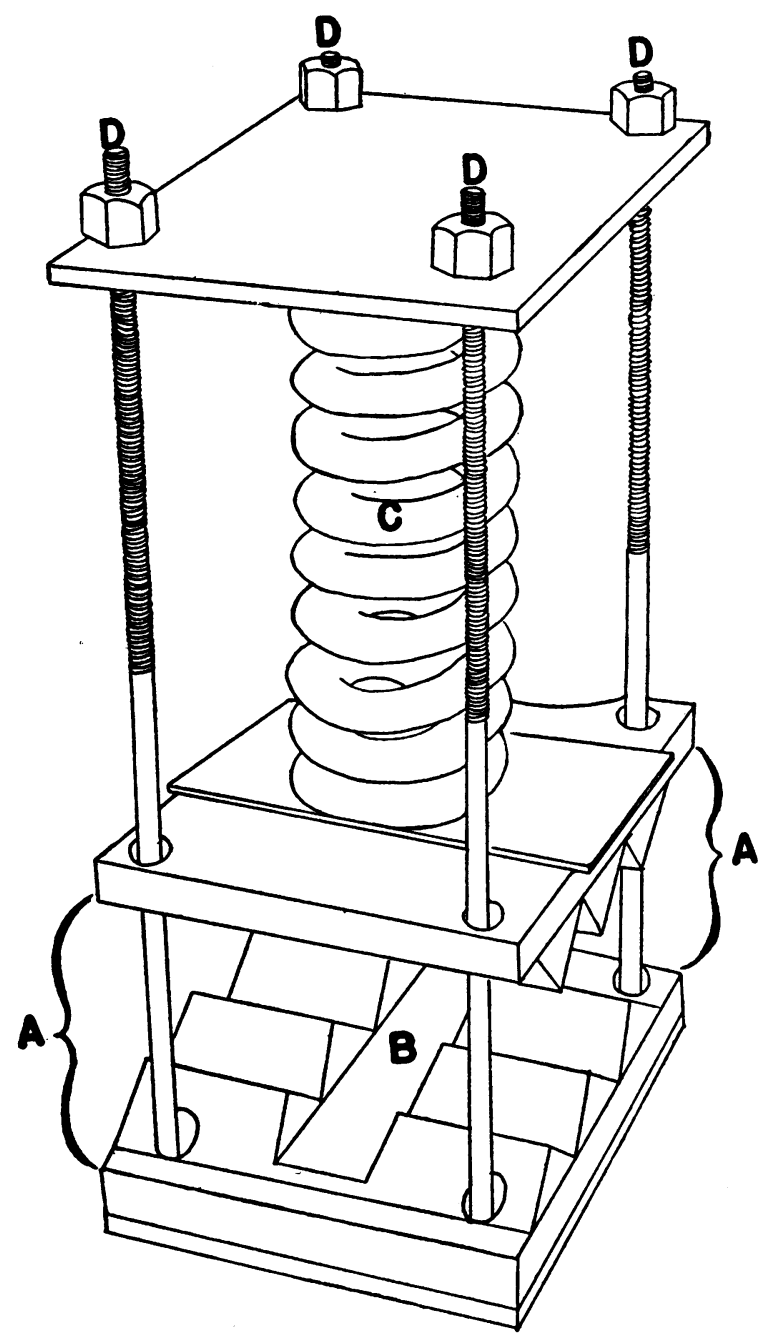

Fig. 1. The Modified Blalock Press

The dog's thigh is placed in the space marked $A . \quad B$ is a groove to accommodate the femur. $C$ is a calibrated knee action spring (from a Buick car). The desired pressure is exerted on the thigh by screwing down the bolts, $D$, until the spring has been compressed the requisite amount.
The surviving dogs were restrained on the table for 12 hours following the removal of the press. If the animal still survived at 12 hours, it was placed on the floor on a leash, with a rubber mat or other soft bedding. As soon as the dog was able to lap water spontaneously (usually within 3 hours after removal of the press), it was offered $150 \mathrm{ml}$. of drinking water at 2-hour intervals. No other aliment was given in the 24-hour period following removal of the press. Dogs alive at the end of 24 hours were counted as survivals; those succumbing naturally in less than 24 hours were counted as deaths from acute shock, unless contributing pathology, not related to shock, was found at autopsy. Autopsies were performed on animals that succumbed and others as indicated, and sections of the tissues were taken for histological examination.

The modified Blalock type of press used consists of 2 jaw boards and 2 three-eighths inch steel plates (Figure 1). The ridged jaw boards contain a central groove corresponding to the position of the femur, so that complete muscle crushing can be obtained without bone damage, or interference from the bone. Ordinarily the skin is not broken by the press. Oversize boltholes in the boards and steel plates allow the 2 jaws to assume the natural angle of the faces of the dog thigh, while the upper jaw and upper steel plate are parallel to each other. This distributes the pressure over the maximum surface of the animal's thigh, and keeps the pressure normal to the thigh surface at a maximum. Due to the impracticability of determining pressures at the skin surface in this arrangement, all pressure values given in the paper refer to over-all pressures. The single large spring between the top jaw of the press and the upper steel plate has been calibrated so that pressures may be read from the calibration curve after measuring the length of the compressed spring. Pressures from 500 pounds to 4000 pounds have been used. A slip of heavy galvanized metal or of steel may be placed at the lower end of the spring to avoid splitting the wooden upper jaw of the press, in the same manner that the lower steel plate protects and supports the wooden lower jaw.

A typical experiment follows.

Animal: 42-917

Date: $3-3-43$

Room temperature: $24^{\circ} \mathrm{C} . \pm 0.5^{\circ} \mathrm{C}$.

Weight of dog: $20 \mathrm{kgm}$.

1:15 P.M.-Rectal temperature: $38^{\circ} \mathrm{C}$.

Pulse: 136

$15 \mathrm{ml}$. blood taken

Serum protein: 5.9 grams per cent

Fibrinogen: 0.32 grams per cent

Hematocrit: $\mathbf{4 2 . 6}$ per cent

Specific gravity: 1.0227

Clotting time: 7 minutes and 35 seconds

1:20 P.M. $-8 \mathrm{ml}$. Nembutal, intraperitoneally

1:45 P.M. $-40 \mathrm{ml}$. blood taken

Serum protein: 5.7 grams per cent

Fibrinogen: 0.30 grams per cent

Whole blood NPN: $26.4 \mathrm{mgm}$. per cent

Hematocrit: 34.4 per cent

Specific gravity: 1.0217 
Clotting time: 9 minutes and 30 seconds

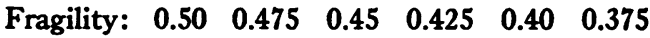

$$
0 \quad 1+2+3+\quad 4+\text { complete }
$$

Rectal temperature: $39.3^{\circ} \mathrm{C}$.

Pulse: 144

2:10 P.M. $-2 \mathrm{ml}$. Nembutal, intraperitoneally

2:15 P.M.-Press put on, 2000 pounds pressure

2:40 P.M. -2 ml. Nembutal, intraperitoneally

3:00 P.M. - Rectal temperature: $38.9^{\circ} \mathrm{C}$.

Pulse: 162

4:00 P.M. $-2 \mathrm{ml}$. Nembutal, intraperitoneally

Rectal temperature: $39.2^{\circ} \mathrm{C}$.

Pulse: 176

5:00 P.M.-Rectal temperature: $37.9^{\circ} \mathrm{C}$.

Pulse: 192

6:45 P.M. - $15 \mathrm{ml}$. blood taken

Serum protein: $\mathbf{5 . 9}$ grams per cent

Fibrinogen: 0.33 grams per cent

Hematocrit: $\mathbf{4 3 . 1}$ per cent

Clotting time: 11 minutes

7:00 P.M.-Rectal temperature: $40.2^{\circ} \mathrm{C}$.

Pulse: 204

7:15 P.M.-Press off

8:00 P.M.-Rectal temperature: $40.0^{\circ} \mathrm{C}$.

Pulse: 200

9:00 P.M.-Rectal temperature: $40.7^{\circ} \mathrm{C}$.

Pulse: 196

Refused water

10:00 P.M.-Rectal temperature: $40.4^{\circ} \mathrm{C}$.

Pulse: 170

10:15 P.M. $-40 \mathrm{ml}$. blood taken

Serum protein: 7.3 grams per cent

Fibrinogen: 0.36 grams per cent

Whole blood NPN: $59.8 \mathrm{mgm}$. per cent

Hematocrit: 64.2 per cent

Clotting time: 3 minutes and 25 seconds

Specific gravity: 1.0218

Fragility: $0.525 \quad 0.50 \quad 0.475 \quad 0.45 \quad 0.4250 .40$

$01+2+3+4+$ complete

Leg measurements:

$\begin{array}{cc}\begin{array}{c}\text { Normal } \\ \text { inches }\end{array} & \begin{array}{c}\text { Traumatized } \\ \text { inches }\end{array} \\ 15-\text { Groin } & -19 \\ 10-2 \text { inches above knee- }-113 / 4 \\ 71 / 2-2 \text { inches below knee- } 81 / 4 \\ 33 / 4-\text { Ankle }\end{array}$

11:00 P.M.-Rectal temperature: $39.6^{\circ} \mathrm{C}$.

Pulse: 180

12:00 midnight-Rectal temperature: $39.3^{\circ} \mathrm{C}$.

Pulse: 186

1:05 A.M.-Dog died

Exitus blood taken

Serum protein: 8.6 grams per cent

Fibrinogen: 0.40 grams per cent

Whole blood NPN: $79.3 \mathrm{mgm}$. per cent

Hematocrit: 75.2 per cent

Clotting time: $\mathbf{5}$ minutes and 20 seconds

Specific gravity: 1.0304
Fragility: $0.55 \quad 0.525 \quad 0.50 \quad 0.475 \quad 0.45 \quad 0.425$

$01+2+3+4+$ complete

Survival time: 6 hours after removal of the press

Leg weights:

Normal: 1840 grams

Traumatized: 2680 grams

Gain in weight of traumatized leg: 840 grams

Heart: Subendocardial hemorrhages

Lungs: Passive congestion

Liver: Passive congestion

Spleen: Hemorrhages

Kidneys: Passive congestion

Stomach and small intestine: Submucosal hemorrhages

Traumatized leg: No gas

\section{CHOICE OF STANDARD PRESSURE}

Using the arbitrary time of 5 hours, which has been adopted by Blalock (1) and by other workers with crush and tourniquet shock $(13,14)$, it was necessary to determine the proper pressure to produce fatal shock in a uniform fashion. Experiments were performed with pressure ranging from 500 pounds to 4000 pounds. As can be seen from Table I, pressures below 1500

TABLE I

The effect of pressure on survival

Press on for 5 hours. Nembutal anesthesia.

\begin{tabular}{|c|c|c|c|c|c|}
\hline $\begin{array}{l}\text { Over-all } \\
\text { pressure }\end{array}$ & $\begin{array}{c}\text { Number } \\
\text { of } \\
\text { animals }\end{array}$ & $\begin{array}{l}\text { Number } \\
\text { surviving }\end{array}$ & Survival & $\begin{array}{c}\text { Average } \\
\text { death } \\
\text { times }\end{array}$ & $\begin{array}{l}\text { Range of } \\
\text { death } \\
\text { times }\end{array}$ \\
\hline $\begin{array}{c}\text { lbs. } \\
500 \\
1000 \\
1500 \\
2000 \\
3000 \\
4000\end{array}$ & $\begin{array}{l}2 * \\
1 \\
6 \\
7 \\
6 \\
1\end{array}$ & $\begin{array}{l}1 \\
1 \\
0 \\
0 \\
1 \\
0\end{array}$ & $\begin{array}{r}\text { per cent } \\
50 \\
100 \\
0 \\
0 \\
17 \\
0\end{array}$ & $\begin{array}{c}\text { hours } \\
7 \\
8 \frac{1}{2} \\
12 \frac{1}{4} \\
7 \frac{1}{4} \\
5 \frac{1}{4}\end{array}$ & $\begin{array}{l}4 \frac{1}{2} \text { to } 21 \\
5 \text { to } 20 \frac{1}{2} \\
2 \frac{1}{2} \text { to } 13\end{array}$ \\
\hline
\end{tabular}

* The animal which succumbed aspirated vomitus. Atelectasis found at autopsy.

pounds can be expected to yield a high percentage of survivals. Results are fairly uniform from 1500 to 3000 pounds, in so far as the proportion of survivals and average death times go. However, autopsy of the animals succumbing shows that although no hemorrhages are detectable in the injured limb with 1500 pounds, there being present only a clear, rapidly clotting plasma-like fluid, numerous punctate hemorrhages are found at 3000 pounds, and intramuscular and intermuscular hemorrhage are prominent features at 4000 pounds. At 2000 pounds, only an occasional case has a few punctate hemorrhages. 
The pressure of 2000 pounds, using this type of press, was therefore adopted as the standard. This is sufficiently above the minimum of 1500 pounds to protect against the effects of size variations in the animals, while not high enough to introduce the additional complication of tissue hemorrhage. The press was applied high against the body so that all the muscles of the thigh from the head of the femur down were included in the press.

Two thousand pounds pressure is sufficient to occlude temporarily, and apparently completely, the normal circulation to the limb while the press is on. Temperature records taken by thermocouples placed at various locations in the limb while in the press show a steady drop in temperature of the tissues, indicating that the circulation is effectively interrupted. On removal of the press, the limb temperatures promptly rise. An example of one such experiment is included in Figure 2. The low pressures

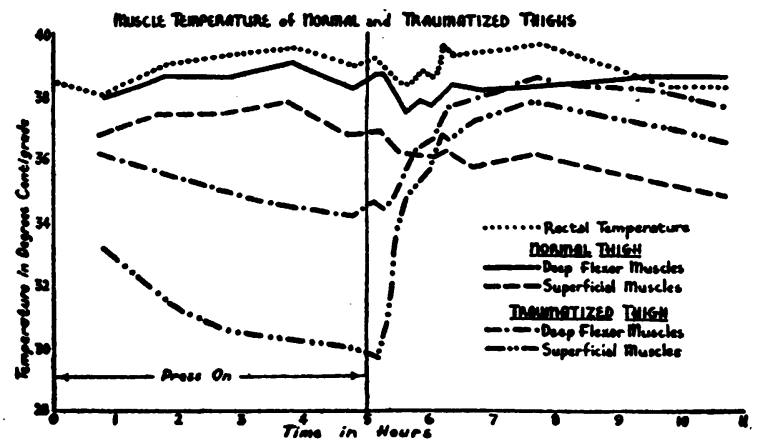

Fig. 2. Temperature of Traumatized Thigh as CoMpared to the Normal Thigh

Press on for 5 hours, 2000 pounds over-all pressure. Nembutal anesthesia. Room temperature $28^{\circ}$ C. Rewarming of the traumatized thigh is rapid after removal of the press. It is to be noted that the temperature of the superficial muscles of the normal thigh drops after removal of the press. This is coincident with cool extremities on palpation.

where survival rates are high (i.e., less than 1500 pounds) probably allow some residual circulation. When the press is removed after pressures of 2000 pounds and above, the pattern of the jaws of the press is clearly marked on the limb. Subsequent to removal of the press, the limb usually, although not always, promptly commences to swell. After 4000 pounds pressure, rewarming of the limb, as well as swelling when present, is relatively slow, leading to the suspicion that the circulation has suffered a more definite obstruction than is the case at the lower pressures. These statements are based on more experiments than appear in the Table.

The temperature in the crushed limb after removal of the press tends to parallel that of the normal side in the latter part of the experiment, and this, in turn, is influenced by the rise or fall of the general body temperature. In this connection, just before the animal develops other evidence of shock, the deep muscle temperatures of the extremities begin to fall and continue to do so during the progression of the shock state (Figure 2). This is probably a result of peripheral vascular constriction. This fall in temperature tends to be more rapid in a cold environment and less at the high room temperatures, or may not appear if the dog's body temperature is either artificially or spontaneously elevated. The latter case usually is fatal.

\section{AIR TEMPERATURE AND SURVIVAL}

Fluctuations of the room temperature, within a surprisingly narrow range, are sufficient to account for the difference between death and survival of the animal in which shock has been produced by the crush injury. Failure to recognize the importance of this factor has undoubtedly been the cause of the disconcerting and confusing irregularities in control experiments, and may have contributed greatly to the difficulty noted in other laboratories as well as by ourselves in standardizing the experimental production of fatal shock as a result of crush injury. It has been found in our experiments that by using a room temperature of $28^{\circ} \mathrm{C}$. the death rate is high; if the environmental temperature is dropped only $12^{\circ} \mathrm{C}$. to $16^{\circ} \mathrm{C}$., almost complete saving of the animals results. At a constant room temperature of $24^{\circ} \mathrm{C}$., between these extremes, there is an intermediate mortality rate. A review of our experiments during 2 summer periods and 1 winter indicates that the environmental (room) temperature has been a definite controlling factor in all our previous experiments.

A different effect is found if one temperature is maintained during the period the animal is in the press, and following removal of the press the 
TABLE II

Effect of temperature on survival

Press on for 5 hours, 2000 pounds over-all pressure. Nembutal anesthesia.

\begin{tabular}{|c|c|c|c|c|c|}
\hline $\begin{array}{l}\text { Room } \\
\text { temp. }\end{array}$ & $\begin{array}{l}\text { Num- } \\
\text { ber of } \\
\text { dogs }\end{array}$ & $\begin{array}{l}\text { Num- } \\
\text { ber } \\
\text { sur- } \\
\text { viving }\end{array}$ & $\begin{array}{l}\text { Sur- } \\
\text { vival }\end{array}$ & $\begin{array}{c}\text { Average } \\
\text { death } \\
\text { times }\end{array}$ & $\begin{array}{l}\text { Range of } \\
\text { death } \\
\text { times }\end{array}$ \\
\hline $\begin{array}{l}16^{\circ} \mathrm{C} . \\
20^{\circ} \mathrm{C} . \\
24^{\circ} \mathrm{C} . \\
28^{\circ} \mathrm{C} .\end{array}$ & $\begin{array}{r}6 \\
7 \\
13 \\
20\end{array}$ & $\begin{array}{l}5 \\
6 \\
5 \\
2\end{array}$ & $\begin{array}{c}\text { per cent } \\
83 \\
86 \\
38 \\
10\end{array}$ & $\begin{array}{c}\text { hours } \\
12 \\
11 \\
9 \\
7\end{array}$ & $\begin{array}{c}\text { hours } \\
5 \frac{1}{2} \text { to } 13 \\
3 \text { to } 21\end{array}$ \\
\hline $\begin{array}{l}16^{\circ} \mathrm{C} \text {. while in- } \\
\text { jury was pro- } \\
\text { duced. } 28^{\circ} \mathrm{C} \text {. } \\
\text { after removal } \\
\text { of press. } \\
28^{\circ} \mathrm{C} \text {. while in- } \\
\text { jury was pro- } \\
\text { duced. } 16^{\circ} \mathrm{C} \text {. } \\
\text { after removal } \\
\text { of press. }\end{array}$ & 10 & 6 & 60 & $9 \frac{3}{4}$ & 6 to $8 \frac{3}{4}$ \\
\hline $\begin{array}{l}\text { Ice packs on } \\
\text { traumatized } \\
\text { extremity. }\end{array}$ & 19 & 18 & 95 & 18 & \\
\hline
\end{tabular}

animal is transferred to another temperature. In these experiments, dogs were kept at $28^{\circ} \mathrm{C}$. for the 5 hours the press was in place, and then removed to $16^{\circ} \mathrm{C}$. following removal of the press, or the reverse procedure was employed. Both of these experiments give mortality rates intermediate between those found when the experimental temperatures were kept constant. The results of these experiments are included in Table II. The temperature at which the injury is produced apparently has an effect upon the subsequent course of events.

Dogs kept in a warm environment while the press is on can be saved even more efficiently, without removal from the warm environment, if immediately upon removal of the press the traumatized extremity is completely invested with ice in cloth bags. The results are summarized in Table II. The ice-bag must be left on the extremity for a period of approximately 4 days. If the ice was removed before the expiration of this period, the dog rapidly became sick, with vomiting and diarrhea, and an elevation of body temperature. Upon replacement of the ice-bags, these symptoms rapidly subsided. Deep temperatures near $20^{\circ} \mathrm{C}$. seem to be optimal for the chilled area. At the end of the 4-day period, after the ice was removed,

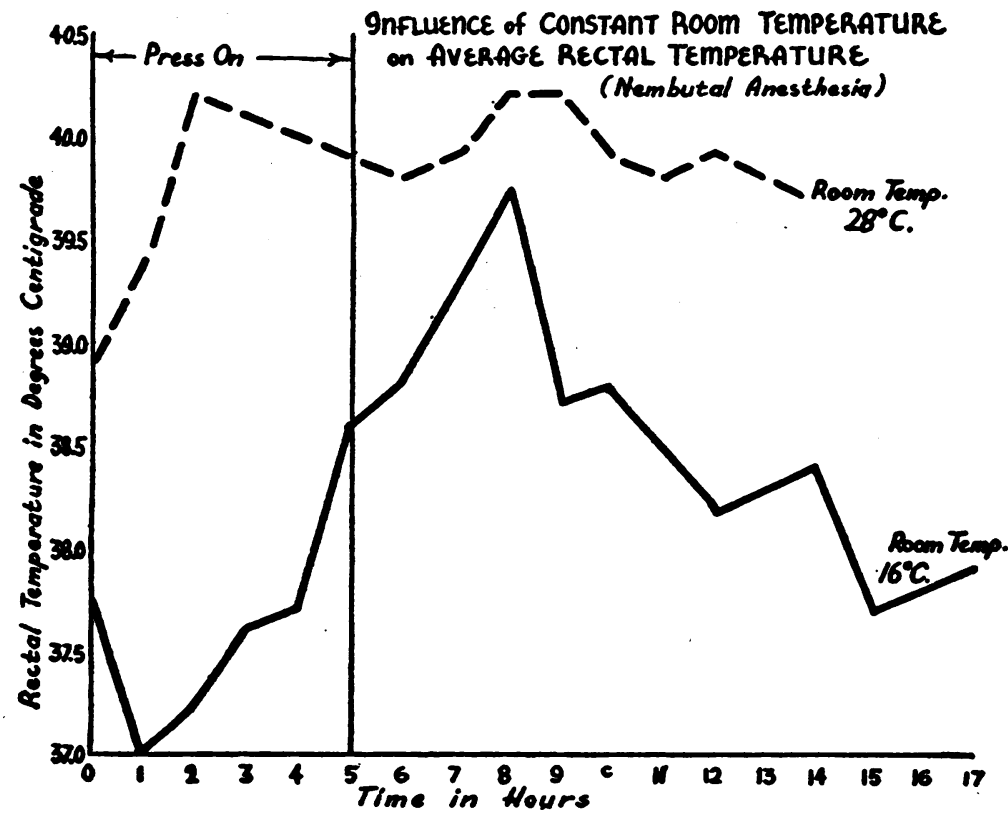

Fig. 3. Average Hourly Rectal Temperature at the ROOM TEMPERATURE INDICATED

The group done in a room temperature of $28^{\circ} \mathrm{C}$. consists of $20 \mathrm{dogs}$, and the group at $16^{\circ} \mathrm{C}$. consists of 6 dogs. The rectal temperature of dogs kept in a room temperature of $16^{\circ} \mathrm{C}$. is distinctly lower than those kept at $28^{\circ} \mathrm{C}$. 
healing was slow and the dogs usually developed a gas gangrene infection of the traumatized limb. This was partially controlled by the administration of sodium sulfadiazine either by mouth or intravenously, maintaining blood levels of about $12 \mathrm{mgm}$. per cent.

It is fairly clear from Figures 3,4 , and 5 that the body temperature of the animals is influenced markedly by the environmental temperature. The animals kept at $16^{\circ} \mathrm{C}$. show an average body temperature distinctly lower than those kept at $28^{\circ} \mathrm{C}$. Also, in the experiments in which animals that had been kept at one temperature and were taken to another temperature at the time the press was removed, the animals succumbing in each group showed progressively higher body temperatures than did the survivors. In transferring from the high temperatures to the low, death occurred in the group which lagged in its fall of body temperature; in transferring from the low to the high temperatures, death occurred in those animals whose body temperatures rose most rapidly to febrile levels. On reviewing for the past 18 months our previous experiments, it was found that the animals which

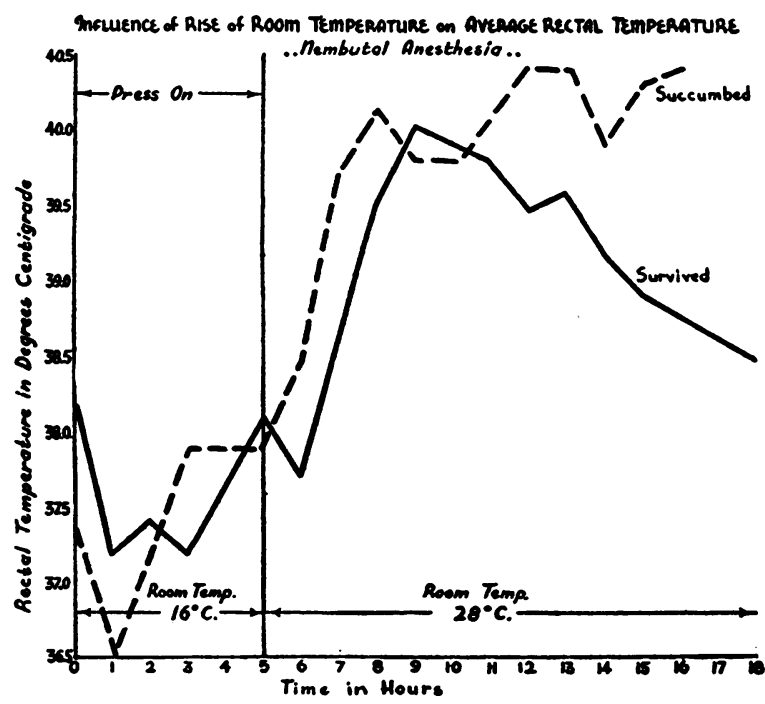

Fig. 4. Room Temperature of $16^{\circ} \mathrm{C}$. While the Press Was On, and $28^{\circ}$ C. After Removal of the Press

Average hourly rectal temperature. There are 6 dogs in the survival group and 4 in the group which succumbed. The rectal temperature rises abruptly on removal to the warm room, and more so in those destined to succumb than in those destined to survive.

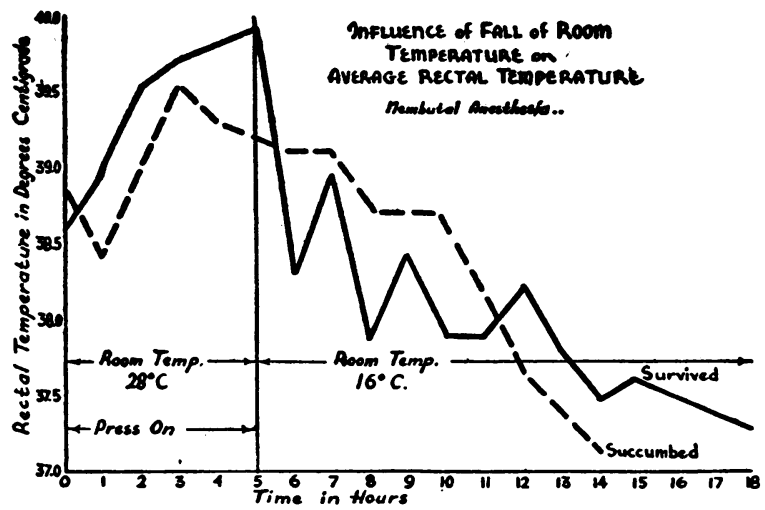

Fig. 5. Room Temperature of $28^{\circ} \mathrm{C}$. While the Press Was On, and $16^{\circ} \mathrm{C}$. After Removal of the Press

Average hourly rectal temperature. There are 4 dogs in the survival group, and 6 in the group which succumbed. The rectal temperature drops abruptly on removal to the cold room, and more so in those destined to survive than in those destined to succumb.

were treated in a room of uncontrolled temperature $\left(26^{\circ} \mathrm{C}\right.$. to $35^{\circ} \mathrm{C}$.) during the hot months of the year behaved like those treated at controlled high room temperatures, while those treated during the cold winter months at uncontrolled room temperatures $\left(15^{\circ} \mathrm{C}\right.$. to $22^{\circ} \mathrm{C}$.) likewise behaved like those in the controlled lower room temperatures. Thus there seems to be no doubt that the high body temperature of the shocked animal is largely a determining factor in the fatal outcome, and that the environmental temperature is a major factor in the final body temperature achieved. The rectal temperatures of the dogs kept in a hot room with ice investing the traumatized thigh are not included in the Figures. The body temperatures of these dogs behaved, in general, like the body temperatures of the dogs injured at a high room temperature and then removed to low room temperature upon removal of the press.

\section{PATHOLOGICAL FINDINGS}

Of the dogs subjected to 2000 pounds pressure in the press, 34 complete autopsy records are available on animals that succumbed in a fairly comparable state and duration of shock at various periods, less than 24 hours after removal of the press. The incidence of pathological findings in this group is as follows: spleen enlargement and hemorrhage, 85 per cent (enlarge- 
ment due in part to Nembutal anesthesia); submucosal hemorrhages of the stomach, 70 per cent; of the small intestine, 32 per cent; hemorrhages in the crushed leg, usually punctate in character, 12 per cent; acute gastric ulcer, 3 per cent. Certain characteristics were looked for only in the later experiments, and are calculated on the basis of 24 autopsies rather than 34. Thus, lung hemorrhages were found in 24 per cent, and gas gangrene of the traumatized extremity in about 12 per cent of the cases. Subendocardial hemorrhages were found in 54 per cent of cases (15). Gas gangrene developed rarely in the experiments conducted at the lower room temperatures, and more frequently at the high temperatures. In the experiments with ice-packs, the dogs usually showed gas gangrene by the fourth day following injury. It should be pointed out that all of these pathological findings, in addition to the characteristic congestion of all the viscera, appear in less than 24 hours, many of them in only a few hours.

Study of sections of the kidney and liver indicates that damage to the renal tubules and central necrosis of the liver are also characteristic of crush shock. Definite kidney damage (usually hydropic degeneration of the tubular epithelium) is visible in animals that have succumbed in as short a time as 3 hours following the removal of the press, and has been seen in almost all the sections examined. The urine output following crush injury in these animals is very scanty. The urine frequently contains red cells, and the supernatant fluid after centrifuging gives a positive benzidine test and a strongly positive protein test.

\section{LABORATORY FINDINGS}

In as much as the animals either succumbed to peripheral circulatory failure or were out of danger within 24 hours following removal of the press, attention has been restricted primarily to the early or critical part of this period. Some animals have succumbed, with all or most of the above changes fully developed, in less than 3 hours after removal of the press. Accordingly, blood changes that occur within the 3 hours immediately following removal of the press may be expected to be of more sig- nificance in tracing the onset and development of the collapse state than those that occur later, after the irreversible phases of the progression have been well established. Therefore, most significance has been attributed to the samples taken 3 hours after the removal of the press, and to their relationship to the 3 control samples that preceded them.

Table III summarizes the results of blood chemical determinations which have shown significant changes during shock as compared to control normal samples. It is to be noted that plasma total proteins did not show any significant change during shock while serum total proteins were increased in concentration. With precautions taken to use a constant concentration of oxalate in all blood samples when an anticoagulant was used, variations in amount of oxalate can be considered minor. However, there is still the possibility that even slight variations of oxalate concentration, when coupled with considerable changes in hematocrit, may result in erratic values for plasma protein values. Such a behavior has been noticed and remarked upon (8) and it was reported that plasma protein values varied with the oxalate concentration. For this reason, and since serum protein values were consistent and gave results which were comparable from animal to animal, in the latter part of the experimental series, serum protein concentrations were done instead of plasma protein concentrations.

Three hours after removal of the press, serum proteins showed, on the average, a rise to 7.1 grams protein per hundred $\mathrm{ml}$. from the control level of 6.0 to 6.2 grams. Only 1 animal in 24 failed to show this upward trend of protein level, and in only 4 was there a change of less than 0.5 gram per hundred $\mathrm{ml}$. On the average, the animals destined to survive showed a smaller rise than those destined to succumb. However, in the individual dog, the change was too variable to predict whether or not it was going to survive.

The non-protein nitrogen control values were quite uniform, averaging $32 \mathrm{mgm}$. per hundred ml. of whole blood. Within 3 hours after removal of the press, the value had risen to an average of $50.9 \mathrm{mgm}$. per cent in the animals which were to survive, and to $59.6 \mathrm{mgm}$. per cent in those destined to succumb. At 24 hours, for 
TABLE III

Blood chemical and physical changes during shock

2000 pounds pressure. Nembutal anesthesia. The values represent averages of the number of dogs shown.

\begin{tabular}{|c|c|c|c|c|c|c|c|c|}
\hline & & $\begin{array}{l}\text { Number } \\
\text { of dogs }\end{array}$ & $\begin{array}{c}\text { Before } \\
\text { anesthesia }\end{array}$ & $\begin{array}{l}10 \text { minutes } \\
\text { after } \\
\text { anesthesia }\end{array}$ & $\begin{array}{l}\text { One-half } \\
\text { hour before } \\
\text { removal of } \\
\text { the press }\end{array}$ & $\begin{array}{l}3 \text { hours } \\
\text { after re- } \\
\text { moval of } \\
\text { the press } \\
\text { (in shock) }\end{array}$ & Exitus & $\begin{array}{l}24 \text { hours } \\
\text { after re- } \\
\text { moval of } \\
\text { the press }\end{array}$ \\
\hline \multirow{2}{*}{$\begin{array}{l}\text { Total plasma protein } \\
\text { (grams per } 100 \mathrm{ml} . \text { ) }\end{array}$} & Survivals & 15 & 5.7 & 5.9 & 5.8 & 5.8 & & 5.2 \\
\hline & Deaths & 26 & 5.8 & 6.0 & 5.7 & 5.6 & 6.1 & \\
\hline \multirow{2}{*}{$\begin{array}{l}\text { Total serum protein } \\
\text { (grams per } 100 \text { ml.) }\end{array}$} & Survivals & 10 & 6.1 & 5.8 & 5.8 & 6.5 & & 5.4 \\
\hline & Deaths & 14 & 6.4 & 6.1 & 6.2 & 7.5 & 7.2 & \\
\hline \multirow{2}{*}{$\begin{array}{l}\text { Fibrinogen } \\
\text { (grams per } 100 \mathrm{ml} .)\end{array}$} & Survivals & 25 & 0.27 & 0.27 & 0.29 & 0.31 & & 0.49 \\
\hline & Deaths & 40 & 0.30 & 0.29 & 0.32 & 0.32 & 0.38 & \\
\hline \multirow{2}{*}{ Serum specific gravity } & Survivals & 11 & 1.0237 & 1.0234 & 1.0237 & 1.0249 & & 1.0215 \\
\hline & Deaths & 14 & 1.0245 & 1.0238 & 1.0244 & 1.0266 & 1.0276 & \\
\hline \multirow{2}{*}{ Hematocrit } & Survivals & 41 & 40.7 & 39.3 & 40.1 & 61.1 & & 49.3 \\
\hline & Deaths & 50 & 42.2 & 40.3 & 41.1 & 60.9 & 66.7 & \\
\hline \multirow{2}{*}{$\begin{array}{l}\text { Non-protein nitrogen } \\
\text { (mgm. per } 100 \mathrm{ml} .)\end{array}$} & Survivals & 25 & & 32.0 & & 50.9 & & 70.4 \\
\hline & Deaths & 37 & & 31.8 & & 59.6 & 78.5 & \\
\hline
\end{tabular}

the survivors, it averaged 70.4 mgm. per cent, while in the animals that had succumbed in less than 24 hours, it averaged $78.5 \mathrm{mgm}$. per cent at exitus. The difference in NPN values between survivors and non-survivors at 3 hours is highly significant statistically (by Fisher's $t$ test).

In one series of experiments, the NPN components, urea, creatine, and creatinine, were determined (13 animals). The blood urea nitrogen parallels very closely the changes in total NPN, and comprises from 30 per cent to 50 per cent of the total NPN. The creatine and creatinine concentration increased 2- to 3-fold during shock over the control values.

Fibrinogen values remained almost stationary during the period before removal of the press. The 3 successive means for this control interval are $0.29,0.28$, and 0.31 grams per hundred $\mathrm{ml}$. Three hours following removal of the press, the mean value was still 0.32 grams per hundred $\mathrm{ml}$. The mean exitus value for the dogs that succumbed was 0.38 grams per cent, while the survivors averaged 0.49 grams per cent at 24 hours. Plotting values against time indicates that this difference is due only to the greater time the survivors had to build up their fibrinogen levels. This increase in fibrinogen following crush injury is in accord with the work of others (16), and has also been reported as occurring during tourniquet shock (17).

Three hours after removal of the press, the average serum specific gravity value rose, from a control level of 1.0237 , to 1.0249 in the case of the survivals, and from 1.0244 to 1.0266 in those that died. Of 25 animals, 2 failed to exhibit this upward trend, and in only 5 was there a change of less than 0.0011 .

The agreement between the serum protein determined by the micro-Kjeldahl method and serum specific gravity is illustrated by Figure 6 . The distribution is much like that shown by Moore and Van Slyke (18). In the earlier part of the experimental series, parallel determinations of plasma specific gravities and plasma protein concentrations were done, measured amounts of potassium oxalate being used as anticoagulant. There was no agreement between these plasma specific gravities and their plasma protein counterpart. The method then was changed in favor of the serum values which were consistent. The possible effect of the oxalate has already been discussed. 


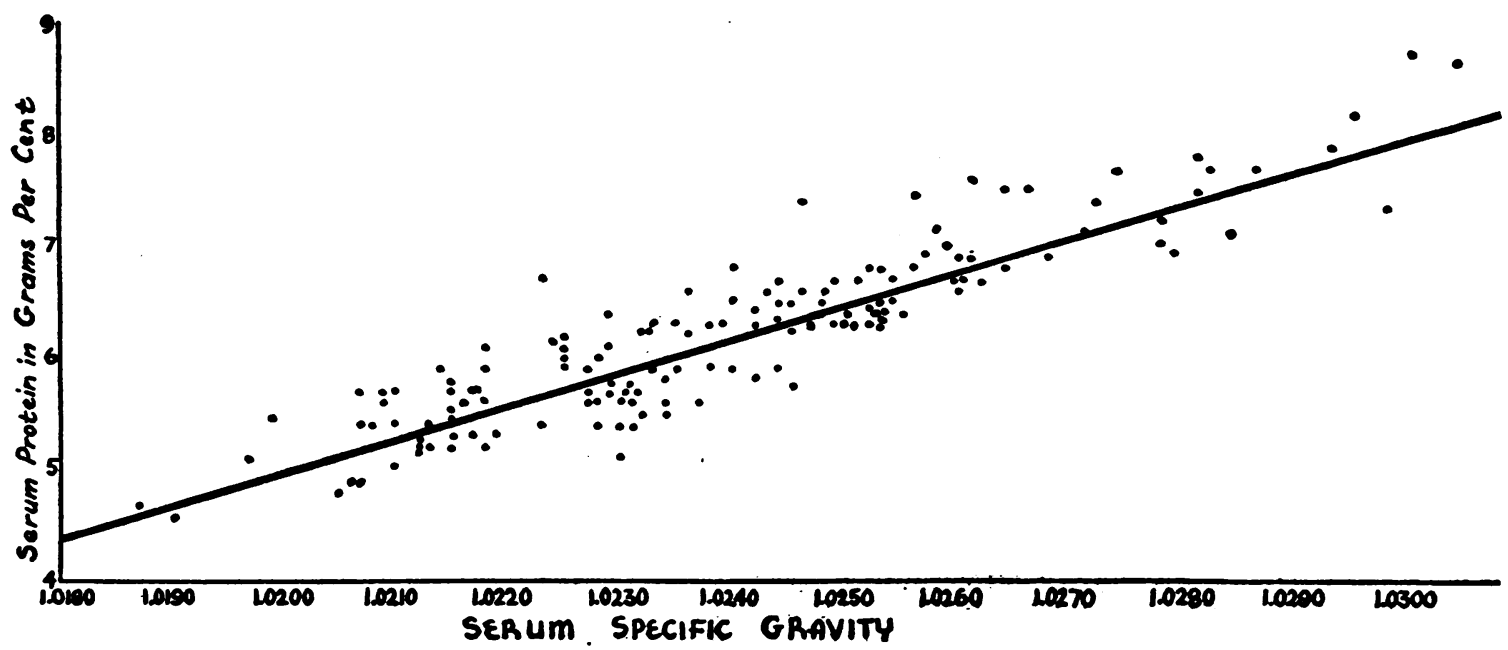

Fig. 6. Serum Protein Concentrations, Determined Chemically, Plotted Against Serum Specific Gravity

Each point represents a parallel determination of serum protein by the micro-Kjeldahl method and serum specific gravity by the pycnometer method.

The mean initial hematocrit for all animals was about 41.5 per cent. The mean value dropped to $\mathbf{4 0 . 5}$ per cent after anesthesia (Nembutal) was induced, but rose to its original level before removal of the press. Within 3 hours following removal of the press, the mean value rose to 61 per cent in both survivors and those destined to succumb. At 24 hours, the survivors' hematocrit dropped to a mean of 49 per cent while the mean exitus level of the nonsurvivors was 67 per cent. It should not be inferred from this that the individual behavior was regular. A given animal might show, and in most cases did show, extreme irregularity as compared to the average. Occasionally, the hematocrit rose following anesthesia; the exitus hematocrit was sometimes lower than the 3-hour sample; and the animals surviving frequently showed greater increase in hematocrit than those succumbing. Initial hematocrit values ranged from 20 per cent to 61.1 per cent, and exitus hematocrit values varied from 38 per cent to 82.8 per cent.

\section{Red cell fragilities}

It had been noticed that hemolysis would be found in many blood samples, particularly near exitus, unless great care were taken in handling the samples, and it was found often in spite of great care.
The osmotic fragility of the erythrocytes was determined by means of the highest concentration of sodium chloride producing complete hemolysis. Tubes were set up containing from 0.275 per cent $\mathrm{NaCl}$ to 0.475 per cent $\mathrm{NaCl}$, in steps of $\mathbf{0 . 0 2 5}$ per cent. One drop of defibrinated blood was added to $5 \mathrm{ml}$. of the salt solution, the tube was mixed thoroughly, and then left to settle for 1 hour. At this time, it was easy to determine the point at which complete hemolysis occurred in the series. Usually the hemolysis range covered 5 tubes.

The initial or control fragility level varied to some extent. In a series of 136 control samples from different dogs, hemolysis occurred over the range from 0.275 per cent to 0.400 per cent $\mathrm{NaCl}$. The mean value was 0.35 per cent. Onethird of the animals showed this mean value; 124 of the 136 ( 90.6 per cent) are included in the range extending from 0.325 per cent to 0.375 per cent $\mathrm{NaCl}$ (one interval each side of the mean). The mode is at 0.325 per cent.

There were 76 dogs in which blood sampling was complete enough for comparative purposes. At 3 hours after removal of the press, 56 of the 76 dogs showed a rise in fragility of from 1 to 4 tubes; 11 showed no change; and 9 showed a drop in fragility of from 1 to 4 tubes. If the groups of dogs are separated into those which survived and those which succumbed, a distinct difference is found. Both groups showed an 
almost normal distribution, but the mode was shifted. For the animals destined to survive, the mean change at 3 hours was +0.86 tubes, with the mode at +1 tube $(0.350$ per cent). For those destined to succumb, the mean change was +1.46 tubes, with the mode at +2 tubes ( 0.375 per cent). In the surviving group, 12 of 35 animals showed no change or a decrease in fragility of 1 to 2 tubes. In 41 animals that succumbed, 4 showed no rise, and 4 showed a drop of 1 tube. On the other hand, 6 dogs that succumbed showed rises of 3 or 4 tubes in contrast to only 2 dogs with similar changes in the group of survivors. These changes are shown in Figure 7.

The rise in fragility is evident as early as 3 hours after release of the press. To determine just how soon after trauma the fragility change was noticeable, fragilities were followed at close intervals in 2 dogs kept in a room temperature of $28^{\circ} \mathrm{C}$. Measurements were started with the pre-anesthetic blood sample, and continued at hourly intervals until the press was removed. Beginning at 10 minutes after removal of the

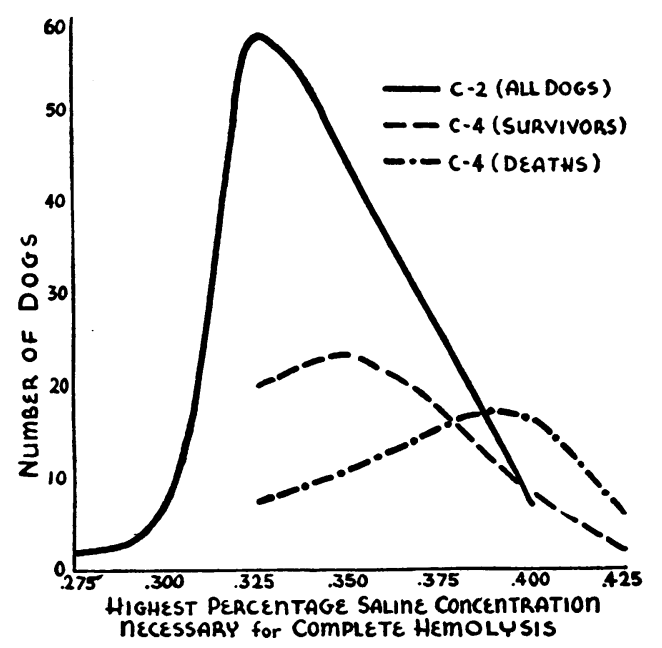

Fig. 7. Erythrocyte Fragility Changes DURING SHOCK

Abscissa values represent highest concentration of saline necessary for complete hemolysis. The solid line curve represents the distribution of fragility of control samples in a total of $136 \mathrm{dogs}$. During shock, the mode and mean are shifted to the right, and more so for those dogs that succumbed than for those that survived. $\mathrm{C}-2$ is the sample taken before the press is applied; C-4, that taken 3 hours after removal of the press when the animal is in shock.

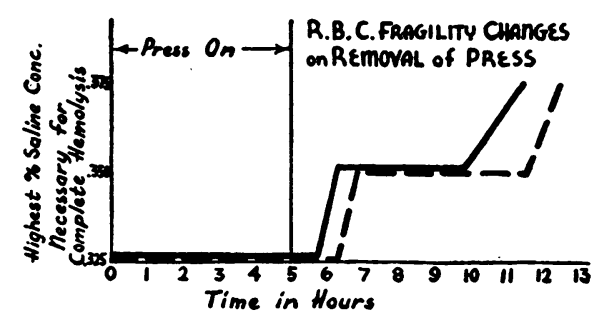

Fig. 8. Erythrocyte Fragility Changes in 2 Dogs

press, determinations were made at 30-minute intervals. The curves obtained are shown in Figure 8. Both dogs started with complete hemolysis at 0.325 per cent saline. Serum specific gravities and red cell counts were also done on the same blood samples used above. Both the specific gravity and cell counts rose abruptly following removal of the press. The curves for these are included in Figure 9.
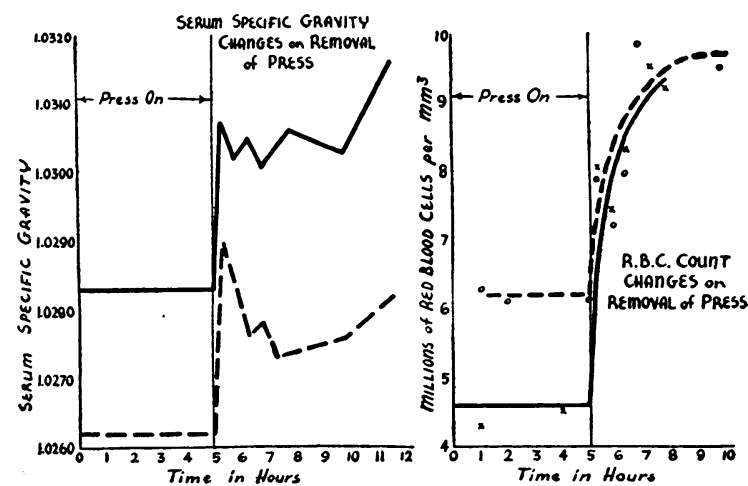

Fig. 9. Red Blood Cell Count and Serum Specific Gravity Changes in 2 Dogs

Both the red count and specific gravity increase abruptly to almost their maximum values $\mathbf{1 0}$ minutes after removal of the press.

On the basis of these results, it seems that a rise in erythrocyte fragility is also fairly characteristic of the shock state, and to a certain extent the degree of rise is a measure of the severity of the shock condition.

\section{DISCUSSION}

It is striking that such a narrow temperature range $\left(12^{\circ} \mathrm{C}\right.$.) seems to make the actual difference between life and death for the dog in shock as a result of a crush injury. Survival is almost always possible in a room temperature of $16^{\circ} \mathrm{C}$., and the standard crush injury is almost uniformly fatal at a room temperature of $28^{\circ} \mathrm{C}$. 
The experiments controlling the room temperature were done during the winter months, at which time the room temperature could be regulated easily without elaborate arrangements. There was no control, however, over the humidity which was relatively low. Whether humidity might also play a controlling rôle in the regulation of the body temperature at a given environmental temperature could not be determined. No optimum was found at $24^{\circ} \mathrm{C}$., such as has been reported (2) for burns.

The body temperatures grossly tend to follow the trend of the environmental temperatures and, on an average, the body temperatures furnish an indication as to the final course of events. The average rectal temperature in those dogs that were injured in a room temperature of $28^{\circ} \mathrm{C}$. was, just before removal of the press, some $1.7^{\circ} \mathrm{C}$. above that of dogs injured in a room temperature of $16^{\circ} \mathrm{C}$. After removal of the press, the difference in rectal temperature was not as marked since the body temperature of the dogs done at low room temperatures rose at this time. Anesthesia may play some part in this situation because the resulting peripheral vascular dilatation may enable the environmental temperature to affect the heat losses or gains during the critical period more directly than might be the case in the unanesthetized animal.

It should be stressed that the changes in rectal temperature which seem to be indicative of whether the animal will survive or not are relatively small. Furthermore, fluctuations over a narrow range of temperature during the critical period may make the difference between life and death. This does not mean that the body temperatures found are lethal per se, but that these small differences are either the symptoms of or the causes of significant changes in other conditions or processes which have not been fully identified as yet.

At the high room temperatures, the mortality rate approximates 100 per cent; at the low room temperatures, the mortality rate approaches zero. Not only is the room temperature while the dog is in shock of importance, but the temperature while the injury is being produced is also of prime importance. This is demonstrated by the experiments in which the dog was changed from one room temperature to another upon termination of the crushing period. In these experiments, the chances of its survival are increased by moving the animal from a room of high temperature to a lower temperature upon removal of the press, and decreased by moving from a low temperature to a higher one, but not to the degree predicted if the animals had been kept at the second temperature for the whole period.

The practical applications of this finding to operating room temperatures are obvious. A procedure which carries with it a high incidence of surgical shock might be performed more safely if the body temperature of the patient is not allowed to rise, or if it is even lowered slightly. This is accomplished most easily by keeping the operating room temperature down, and by avoiding too much insulation or too many covers on the patient. The avoidance of heat in post-operative care must also be stressed. It is obvious from our experiments that the application of heat, in the case of the dog, is one of the most certain methods of precipitating a fatal outcome with circulatory collapse.

In the absence of means of lowering environmental temperatures, under military conditions or in emergencies, the local applications of ice, if complete enough, may serve to save the shock patient with a traumatic injury. However, as shown in the dog experiments, toxemia is likely to develop if the chilling is not continued for a period far in excess of that during which shock itself is usually a factor. Furthermore, skin sloughing, other necrotic changes, and a high incidence of intrinsic and spontaneous infection (gas gangrene) were found in the unsterile experiments with limbs invested in wet ice-bags for long periods (4 days).

The mechanism underlying the erythrocyte fragility changes which we have described is at present unknown. It is unlikely that it is due to stasis of blood in the traumatized extremity since the first blood coming from the femoral vein at removal of a tourniquet in place for 5 hours failed to show any fragility change from the control. The erythrocyte fragility rise occurring with blackwater fever has been attributed to a decrease in the $\mathrm{pH}$ of the blood (19). It is questionable whether the degree of 
pH produced by the mild acidosis during shock is enough to bring about these fragility changes.

In the dogs succumbing to acute peripheral circulatory failure, there is extensive tubular epithelial degeneration in the kidneys, and evidence of degeneration of the cells adjacent to the central veins in the liver. The kidney damage occurred in 100 per cent of the fatal cases, and has been found as early as 3 hours following removal of the press. The increasing blood NPN, the increased urinary protein, and the curtailed urinary output all confirm the kidney damage seen in sections. There is a possibility that not all the NPN is a reflection of kidney damage. It has been suggested $(20,21)$ that the azotemia in burn shock may be due in part to polypeptide nitrogen. This also may be the case in our experiments since large amounts of muscle are crushed.

The characteristics most quickly showing shock changes, in our experiments, are the blood NPN, red cell fragility, hematocrit, red cell counts, and serum specific gravity (serum protein). The NPN changes are to a large extent probably indicative of the kidney injury already discussed. The hematocrit rise and increased serum protein concentration are a reflection of the hemoconcentration caused by loss of fluid into the traumatized limb (see second paper in this series).

If one is looking for early clinical evidence of peripheral circulatory failure, parallel to or as substitute for blood pressure determinations, or is looking for a clue to causative factors in the vicious circle that develops, they should be sought first in the above group of characteristics. Deep peripheral muscle temperatures yield the first tangible evidence, but thermocouples for such measurements are not readily available. Skin temperatures are not always a true reflection of the situation beneath.

The optimum point in temperature effect upon burn shock as reported (2) may be peculiar to the complicated situation in the severe burn shock used in those experiments. The optimal point "in the neighborhood of mammalian body temperature" in shock (3) is probably influenced by the particular methods of temperature control used by these authors. Their results with temperatures in the vicinity of freezing are com- parable to ours with the local application of icebags. Apparently, the toxic condition develops more slowly under the action of ice. Animals treated at $16^{\circ} \mathrm{C}$., without ice, show a much less complicated reaction after the initial 24 hours. In the case of refrigeration anesthesia, when used in conjunction with a tourniquet, with amputation as the end in view, such toxicity is of no importance.

\section{SUMMARY}

For the standardized experimental production of traumatic shock, the modified Blalock press may be used, if the over-all pressure and the environmental temperature are controlled.

(1) The pressures used must be sufficiently great to assure occlusion of all major blood vessels leading into the extremity.

(2) With the lower lethal pressures (1500 to 2000 pounds), there is little or no hemorrhage to complicate the picture; with higher pressures (3000 pounds or over), hemorrhage into the tissues can be produced as desired.

(3) Using a standard pressure of 2000 pounds, low environmental temperatures $\left(16^{\circ} \mathrm{C}\right.$.) afforded almost complete protection from death. To produce death uniformly, room temperatures of $28^{\circ} \mathrm{C}$. were necessary. Intermediate temperatures produced intermediate mortality rates.

(4) Alteration of the temperature following production of the injury exerts an incomplete effect as compared with constant exposure to the subsequent room temperature.

(5) With a high environmental temperature, local application of ice to the injured limb affords almost complete protection from death.

(6) Both physiological and morphological kidney damage of a temporary nature follow crushing injury within a very short span of time.

(7) Gastrointestinal submucosal hemorrhages and subendocardial hemorrhages are very common pathological findings. Less frequently, degeneration of the central liver lobule cells is found.

(8) The blood chemistry changes are mainly those associated with hemoconcentration and renal damage (rising hematocrit and red count, rising non-protein nitrogen, serum protein, and serum specific gravity). 
(9) A hitherto unreported rise in the fragility of the red cells is also noted, apparently varying in extent with the severity of shock.

(10) Serum specific gravity can be employed to determine serum protein concentration, but plasma specific gravity in the presence of a rising hematocrit and using potassium oxalate as anticoagulant is not a reliable index of the protein concentration.

\section{CONCLUSION}

In order to obtain a reproducible standardized shock experiment with the Blalock type of crusher, it is necessary to use over-all pressure of 2000 pounds for 5 hours on one complete upper thigh under Nembutal anesthesia with the room temperature at $28^{\circ} \mathrm{C}$. or above.

Any variation in these several stipulations may change the picture enough to prevent the onset of fatal shock.

We wish to acknowledge the loyal, untiring and cooperative participation of the technical group who made these protracted experiments possible: George Casarett, Betty Mulryan, Marion Wesley, John Thomas, Jerry Biondi, Marlene Falkenheim, Edward Mulligan, and Elizabeth Vittum. We also wish to acknowledge the technical advice of Mr. Francis Bishop on equipment.

\section{BIBLIOGRAPHY}

1. Blalock, A., Principles of Surgical Care, Shock and Other Problems. C. V: Mosby Co., St. Louis, 1940.

2. Moon, V. H., Shock: Its Dynamics, Occurrence and Management. Lea and Febiger, Philadelphia, 1942.

3. Wiggers, C. J., The present status of the shock problem. Physiol. Rev., 1942, 22, 74.

4. Blalock, A., and Duncan, G. W.; Traumatic shockA consideration of several types of injuries. Surg., Gynec. and Obst., 1942, 75, 401.

5. Elman, R., Cox, W. M., Jr., Lischer, C. E., and Mueller, A. J., Mortality in severe experimental burns as affected by environmental temperature. Proc. Soc. Exper. Biol. and Med., 1942, 51, 350.

6. Wakim, K. G., and Gatch, W. D., The effect of external temperature on shock. J.A.M.A., 1943, $121,903$.
7. Blalock, A., and Mason, M. F., A comparison of the effects of heat and those of cold in the prevention and treatment of shock. Arch. Surg., 1941, 42, 1054.

8. Cullen, G. E., and Van Slyke, D. D., Determination of the fibrin, globulin, and albumin nitrogen of blood plasma. J. Biol. Chem., 1920, 41, 587.

9. Koch, F. C., and McMeekin, T. A new direct nesslerization micro-Kjeldahl method and a modification of the Nessler-Folin reagent for ammonia. J. Am. Chem. Soc., 1924, 46, 2066.

10. Karr, W. G., A method for the determination of blood urea nitrogen. J. Lab. and Clin. Med., 1924, 9, 329.

11. Folin, O., and Wu, H., A system of blood analysis. J. Biol. Chem., 1919, 38, 81.

12. Brown, H. R., Jr., and Clark, W. F., Plasma specific gravity and control of fluid administration in artificial fever. Proc. Soc. Exper. Biol. and Med., 1939, 40, 490.

13. Allen, F. M., Physical and toxic factors in shock. Arch. Surg., 1939, 38, 155.

14. Swingle, W. W., Remington, J. W., Kleinberg, W., Drill, V. A., and Eversole, W. J., An experimental study of the tourniquet as a method for inducing circulatory failure in the dog. Am. J. Physiol., 1942, 138, 156.

15. Lewis, R. N., and Nickerson, N. D., Prolonged adrenalin hypertension and subsequent circulatory failure. Proc. Soc. Exper. Biol. and Med., 1942, $51,389$.

16. Foster, D. P., and Whipple, G. H., Blood fibrin studies: fibrin values influenced by cell injury, inflammation, intoxication, liver injury and the Eck fistula. Am. J. Physiol., 1922, 58, 407.

17. Mylon, E., Winternitz, M. C., Katzenstein, R., and de Süto-Nagy, G. J., Studies on mechanisms involved in shock. Am. J. Physiol., 1942, 137, 280.

18. Moore, N. S., and Van Slyke, D. D., The relationships between plasma specific gravity, plasma protein content and edema in nephritis. J. Clin. Invest., 1930, 8, 337.

19. Smith, F., and Evans, R. W., Effect of the $\mathrm{pH}$ of the blood on haemolysis, with special reference to blackwater fever. Brit. M. J., 1943, 1, 279.

20. Duval, P., Roux, J. C., and Goiffon, R., Essai sur l'intoxication par les polypeptides. Presse méd., 1934, 42, 1785.

21. Lambret, O., Driessens, J., and Malatray, H., Diminution, sous l'action de l'insuline seule ou associbe du glucose, de l'hyperpolypeptidémie secondaire aux destructions cellulaires. Compt. rend. Soc. de biol., 1936, 123, 12. 